\title{
Paraoxonase1 and its relationship with Parkinson's disease
}

\author{
Ali Mota ${ }^{1}$, AliAkbar Taheraghdam ${ }^{2}$ and Mohammad Valilo ${ }^{1,2}$ \\ ${ }^{1}$ Department of Clinical Biochemistry, Faculty of Medicine, Tabriz University of Medical Sciences, Tabriz, Iran \\ ${ }^{2}$ Neurosciences Research Center, Tabriz University of Medical Sciences, Tabriz, Iran
}

\begin{abstract}
This study reviews current understanding of relationship of paraoxonase1 polymorphisms and activity of paraoxonase1 in Parkinson's Disease (PD). Paraoxonase 1 (PON1) is involved in the detoxification of insecticides and pesticides and metabolisms of these toxins. Two polymorphisms within the gene affect the activity of paraoxonase. In One of them a methionine replaces with leucine at position 54 (M54L) and the other a glutamine change to arginine variant at position 192 (Q192R). There are some evidences show the genetic polymorphisms of PON1 can protect against organophosphates such as paraoxon and diazinon. Results of studies that investigate these associations are controversial. There was no significant association between PON1-1 92Q/R alleles and risk of developing PD and also there is no evidence for an association between PON 1-192 polymorphism and development of PD, however, a study found that the 192R alleles were risk factor for developing PD. These polymorphisms explain only some of the variations in serum PON1 activity; thus, the other critical test of the hypothesis is likely to be whether low serum PON1 activity is associated with Parkinson disease or not. In this review we summarize current knowledge from PON1 association studies regarding the interaction between gene polymorphisms and activity of PON1 with the risk of PD.
\end{abstract}

\section{Introduction}

Parkinson's disease was first described in 1817 by an English doctor [1], although the reports of possible parkinsonian syndromes dating back many years ago $[2,3]$. PD is the most common neurodegenerative disorder just after the Alzheimer disease among the elderly [4,5]. Although the median age at onset PD is about 60 years, clinical diagnosis may occur after loss of 30 to $50 \%$ of substantia nigra dopaminergic neurons of PD [6]. The PD phenotype may occur only when $60-70 \%$ of substantia nigra neurons stop functioning [7]. PD leads to rigidity, slowness of voluntary movement and postural instability [4]. in the advanced stages, cognitive and mood disorders are also common [8].

Diagnosing of PD is typically done by the presence of some intracytoplasmic inclusions, known as "Lewy bodies", which are primarily composed of $\alpha$-synuclein protein aggregates [9]. Parkinson disease arise from neuronal loss, which mainly affecting dopaminergic neurons of the substantia nigra [10]. with a prevalence of 5 million individuals world -wide [11]. The Formation of the Parkinson's disease is arisen from a combination of genetic and environmental factors, which likely interact with each other. Epidemiological studies have indicated that environmental factors such as pesticides may increase risk of idiopathic Parkinson's disease (PD) [12]. Environmental factors are apparent causes of the 'sporadic' Parkinson's disease [13,14]. In addition to the environmental factors, sporadic autosomal recessive form of $\mathrm{PD}$ a candidate gene (Parkin) on human chromosome 6q25.2-q27-has been identified [15]. The risk in relatives has been reported to be threefold higher than in the general population [16]. In 1985, it was reported that familial susceptibility to PD might be mediated by genetic variability of enzymes involved in the detoxification of neurotoxins [17]. It has been widely believed that polymorphic variations in xenobiotic metabolizing enzymes, such as glutathione transferase, CYPs and paraoxonase, may affect PD risk by altering the detoxification of pesticides and other putative neurotoxins [18-20]. A number of case-control studies and prospective studies have shown a significant association between pesticide exposure and risk of PD [21,22], whereas other studies have failed to demonstrate such association $[23,24]$.

\section{Paraoxonase1}

The Paraoxonase (PON) gene family contains three different members (PON1, PON2 and PON3), and exhibits anti-oxidative characters principally in the blood circulation [25]. Human PON genes share approximately $70 \%$ identity at the nucleotide level and approximately $60 \%$ identity at the amino acid level [26]. Human PON2 and PON3 lack or have very limited paraoxonase and arylesterase activities, but they are similar to PON1 in that both hydrolyze aromatic and long-chain aliphatic lactones, e.g. $[27,28]$. PON1 is not found in the blood of fishes, birds and most reptiles. The enzymes also classified by Norman Aldridge [29]. Paraoxonase (PON1; EC 3.1.8.1; formerly EC 3.1.1.2) is a calcium-dependent serum enzyme belonging to the class of A-esterases [29], this enzyme is a protein of 354 amino acids with a molecular mass of $43 \mathrm{kDa}$ [30,31]. It is a glycoprotein synthesized in the liver and secreted into the blood [32]. Paraoxonase1 in the plasma associated with High-Density Lipoproteins (HDL) [33-35].

The gen of this protein is collocated on the long arm of chromosome 7 between q21.3 and q22.1 with other members of its family [36,37]. Regarding the roles of organophosphates in etiology of PD, PON1 is the main means of protection of the nervous system against the neurotoxicity of organophosphates [38,39]. PON1 has two activities; one paraoxonase activity that breakdown paraoxon, a toxic metabolite of the parathion and the other activity is arylesterase that breakdown phenyl acetate to phenyl lactate [32]. Mammal serum paraoxonase is also hydrolyze the active metabolite of other OPs insecticides,

${ }^{\star}$ Correspondence to: Mohammad Valilo, Department of Clinical Biochemistry, Faculty of Medicine, Tabriz University of Medical Sciences, Tabriz, Iran, Tel: +989380540895; E-mail: valilo.biomed@gmail.com

Key words: Parkinson's disease, Paraoxonase, Pesticide, Polymorphism

Received: February 06, 2019; Accepted: February 25, 2019; Published: February 26, 2019 
such as chlorpyrifos, diazinon, and of nerve toxins such as sarin and soman [40]. Lactone-containing drugs-spironolactone, mevastatin, simvastatin, and lovastatin have been identified as substrates for PON1 [41]. Such aldehydes can also be hydrolyzed by PON1. Figure 1 point to the metabolisms of the some organophosphate by PON1. On the other hand this enzyme contain a histidine aminoacid at position (115, 134, 155 and 243) and cysteine at the (42, 248 and 353) position, in active site. This histidine is essential for esterase activity and cysteine is essential for hydrolase activity, thus zinc or nickel may bind to histidine. Other metals (e.g. mercury) or smoking extract constituents may interact with Cysteine (Cys) [42]. PON1 variants may represent a biomarker for identifying individuals susceptible to organophosphorus neurotoxicity leading to neurodegeneration and PD [43]. On the other hand this enzyme has been shown to be inactivated by oxidative stress and many antioxidative nutrients [25].
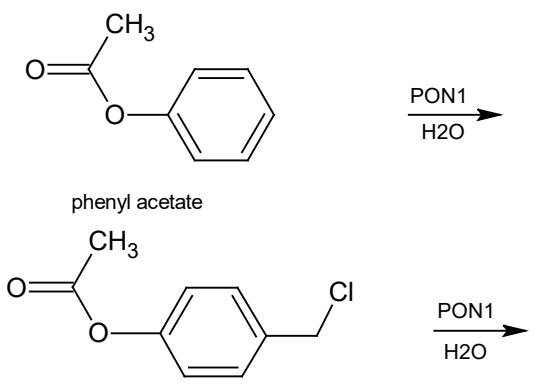<smiles>CCOP(=S)(OCC)Oc1ccc([N+](=O)[O-])cc1</smiles>

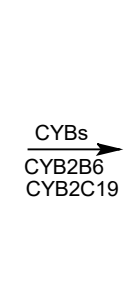<smiles>C=[N+](C)c1ccc(O)cc1</smiles>

\section{Paraoxonase1 polymorphism}

Studies have shown PON1 polymorphisms generated variable susceptibility to different diseases. As mentioned earlier PON1 have Two common coding polymorphisms, a leucine to methionine substitution at position 54 (L54M, rs854560) and a glutamine to arginine substitution at position 192 (Q192R, rs662), which influence the PON1 activity [44-46]. The PON 1 L55M polymorphism has been associated with variability in PON1 concentration and PON1 activity in plasma [46-48]. whereas the PON1 Q 192 R polymorphism has been shown to affect only the activity of PON1 [49]. The PON1 polymorphisms affect the catalytic abilities of this enzyme. The $\mathrm{R}$ allele at position 192 hydrolyzes paraoxon faster than the Q allele but hydrolyzes diazoxon slowly. Then, homozygotes for the B allele are poor metabolizer of organophosphate such as diazoxon, soman and sarin.<smiles>CCOP(=O)(O)OCC</smiles>

diethyl hydrogen phosphate<smiles>Oc1ccccc1</smiles>

pheno<smiles>Oc1ccc(CCl)cc1</smiles><smiles>CC(=O)[O-]</smiles><smiles>CCOP(=O)(OCC)Oc1ccc([N+](=O)[O-])cc1</smiles><smiles>CCOP(=S)(OCC)Oc1nc(Cl)c(Cl)cc1Cl</smiles>

Chlorprifos<smiles>CCOP(=O)(O)OCC</smiles><smiles>CCOP(=O)(OCC)Oc1nc(Cl)c(Cl)cc1Cl</smiles>

Chlorprifos oxon<smiles>Oc1nc(Cl)c(Cl)cc1Cl</smiles> 
The plasma concentration of the enzyme in M allele at position 54 is lower from L54 allele. Thus, R192 and L54 might be markers of higher activity of PON1 [46,50-54]. In other words, plasma of homozygous individuals for the wild-type Leu-allele of the rs 854560 polymorphism has higher PON1 mRNA, protein and higher PON1 activity than homozygous for Met-allele carriers, while heterozygous carriers have intermediate mRNA, protein levels [48,55]. Several previous studies showed the association of one or both of these polymorphisms with PD. Akhmedova et al. reported that the M54 allele increase susceptibility to PD in a Russian population [56]. A further evidence for this association was shown in a Swedish case-control study. Kondo and Yamamoto described a significant increase of the R192 allele in PD patients from Japan in comparison to healthy controls [15]. However, some studies indicated there is no an association between PON1 polymorphisms an Parkinson's disease [57]. The aim of the present study includes investigation of both the M54L and the R192Q allele, genotype and haplotype distribution in PD patients and healthy subjects. In addition to these polymorphisms, some investigators have recently detected polymorphic mutations in the promoter region of PON1 gene, in particular, the $\mathrm{T}(107) \mathrm{C}$ promoter polymorphism has been shown to affect PON1 gene expression and enzymatic activity [58]. Table 1 summarizes the evidence for an association between PON1 L55M and Parkinson's disease. Moreover, another study showed the association of R192Q allele with PD.

\section{Sources of variation in PON1 activity}

PON1 activity has been shown to be regulated both genetically and by post translational modifications $[59,60]$. PON1 diurnal activity is quite constant. Serum paraoxonase activity significantly decreased with age (r 1/4 2 0:38; p, 0:0001); however, its arylesterase activity and its concentration in the serum did not change significantly by aging. Thus, the decrease in PON1 activity may contribute to the increased susceptibility of HDL to oxidation; decreased in detoxification of organophosphates because of aging and oxidative damage. In newborns, PON1 activity until 6 months age is very low, suggesting that newborns can be significantly more sensitive to poisoning by pesticide than adults [50]. In rats, no differences were found in plasma and liver PON1 activity between 3- and 24-month-old animals [61]. Recent investigations have reported a progressive decrease in PON1 activity in elderly humans. More over many other factors can affect the PON1 activity and concentration. Some factors such as Dietary cholesterol, alcohol use, and vitamin $\mathrm{C}$ associate with an increase in AREase activity. And others like iron and folic acid can decrease AREase activity [62]. Triolein supplementation maybe increase the serum PON1 activity; whereas fish oil reduce this enzyme and tripalmitin not affect it [63]. The effects of various dietary fats on PON1 status have been evaluated in rats. Interestingly, PON1 activity in mice and humans can be increases with feed Oleic acid $[64,65]$, others studies shows that Aspirin

Table 1. Genetic association studies about the co-relation of PON1 polymorphism and PD risk

\begin{tabular}{|l|l|l|l|}
\hline Study & PD Patients & Controls & PD Susceptibility \\
\hline Kondo et al. [15] & 166 & 252 & Increased risk for MM \\
\hline Akhmedova et al. [56] & 117 & 207 & Increased risk for MM \\
\hline Carmine et al. [102] & 114 & 127 & Increased risk for MM \\
\hline Clarimon et al. [5] & 144 & 135 & No influence \\
\hline Fong et al. [57] & 125 & 162 & No influence \\
\hline Đurić et al. [103] & 106 & 7 & Increased risk for MM \\
\hline Dick et al. [104] & 767 & 1989 & No influence \\
\hline Manthripragada et al. [20] & 351 & 363 & Increased risk for MM \\
\hline Wingo et al. [105] & 566 & 719 & No influence \\
\hline
\end{tabular}

use associated with high serum levels of paraoxonase activity [66] and synthesis of the PON1 protein as well as activity reduced by glycation of this enzyme [60].

In addition to PON activity, PON1 concentration change with genetic polymorphisms. Experimental evidence showed that serum activity in healthy subjects is directly related to protein concentration. Homozygous BB individuals have higher PON1 concentrations than homozygous AA. Moreover, heterozygous $\mathrm{AB}$ individuals have an intermediate level. It was shown the 55 polymorphism also affected the PON1 concentration. However it could not be found such effects in healthy population [67]. Considering the role of PON1 in PD, the concentration and activity of this enzyme can be different in Parkinson's patients and healthy subjects. Serum PON1 activity were significantly lower in patients than in healthy individuals and this different would be expected based on age alone [7]. Aryl esterase activity of the PON1 protein was significantly higher in $\mathrm{PD}$. healthy subjects suggesting that paraoxonase activity of PON1, but not aryl esterase activity of PON1, is causally involved in the progression of PD [7].

\section{Other disease association with PON 1}

PON1 activity can be regulated genetically and environmentally [60]. One of the most important roles of the PON1 is protection of LDL and HDL against oxidation induced by copper ions as well as by other free radicals [68]. This protection of PON1 is most probably related to the hydrolyzing of some activated lipids [69] and other lipid peroxide products [68] which are produced during the acute phase response. PON1 activity has been demonstrated decrease by LPS (lipopolysacaride) [70] or TNF $\alpha$ /IL -1B explosion but increase with IL-6 [71]. Regarding the roles of these factors, activity of PON1 can be changed in different inflammatory and infectious diseases. PON1 activity has been observed decrease in the serum of patients diagnosed with chronic hepatitis [72], rheumatoid arthritis [73], multiple sclerosis [74], diabetes mellitus [75], atherosclerosis, Alzheimer dementia and cancers [76-79]. Also decrease in PON1 activity levels were reported in radiology workers exposed to long-term ( $>5$ years) ionizing radiation [80].

\section{Prostate and ovarian cancers}

These types are the most common cancers in developed countries. The serum paraoxonase eliminates carcinogenic radicals [81,82]. A study in Finnish man found a new common mutation in the coding region of the PON1 gene, termed $\mathrm{I} 102 \mathrm{~V}$, that was strongly associated with an increased risk of prostate cancer also PON1 polymorphism were significantly associated with epithelial ovarian cancer $[83,84]$.

\section{Myocardial infarction}

PON1 activity in patients who have survived a myocardial infarction was reported to be lower $[85,86]$.

\section{Diabetes}

Presence of PON1-55 MM and PON1-192 QQ genotypes related with weaker diabetes control than RR genotypes. other studies like this emphasized above findings $[87,88]$.

\section{Lung cancer}

It has been emerged the serum PON1 activity in patients with LC compared to healthy individuals is found to be significantly lower [89].

\section{Breast cancer}

The L55M polymorphism, make lowers paraoxonase activity by decreasing the amount of this enzyme present in blood. women with 
the MM genotype for this polymorphisms had a $57 \%$ higher incidence of breast cancer and an 85\% higher incidence of invasive breast cancer [90].

\section{Rheumatoid Arthritis (RA)}

It was shown that increased amount of ROS in plasma may be a sign of rheumatoid arthritis. Baskol et al. reported that increased ROS levels in RA might result in decreased antioxidant PON1 activity [91].

\section{Cirrhosis}

Studies found that PON1 activity was lower in patients with cirrhosis than in those with hepatitis. This reduction in activity of PON1 was considered as a consequence of an altered synthesis and/or secretion of HDL. Alterations of the structure and circulatory levels of HDL was attributed to the hepatic LCAT activity which is frequently affect by chronic liver diseases $[92,93]$.

\section{Atherosclerosis}

Animal models demonstrated that PON1 deficiency was related to a susceptibility of LDL and HDL to oxidation and atherosclerosis development [94,95].

\section{Coronary artery disease}

Studies indicate that PON1 in human is significantly associated with CAD risk $[96,97]$ and its activity is lower among individuals and populations with CAD.

\section{Depression}

A study of the association of paraoxonase1 Q192R polymorphism with depression among a random sample of 3266 British women, suggested that there was an association of PON1 Q192R polymorphism with symptoms of depression [98].

\section{Other disease}

The studies of PON1 polymorphism, activity or levels found a relationship between PON1 with Age-Related Macular Degeneration (AMD). The mechanism(s) for PON1-mediated protection against AMD remains to be determined. A study supported a role for the Q192R polymorphism in decreasing susceptibility to AMD [99]. Saeed et al. found a significant association of variants in the Paraoxonase gene cluster and sporadic ALS in Gulf War veterans [100]. Finally, Paraoxonase activity showed an inverse association only with sperm concentration, and arylesterase activity was not associated with any semen quality parameter [101].

\section{Conclusion}

Multiple genetic and environmental risk factors are known to increase susceptibility to the development of PD. Each factor individually may have a minor effect however their interaction may prove sufficient to cause PD. Over the past few years, an increasing number of studies have attempted to identify paraoxonasel relationship with PD. Our analysis shows that people work with organophosphates are at significantly increased risk of PD. The association of organophosphates with PD may be related to PON1. PON1 would thus seem worthy of further study as an etiologic factor in the development of PD and perhaps other diseases. To date, accepted that both PON1 L55M and PON1 Q192R polymorphisms have been unequivocally associated with PD. Our review of the results of former studies shows that paraoxonase 1 polymorphism may have influence on PD development. And also, it suggests that paraoxonase activity but not aryl esterase activity of PON1 is causally involved in the progression of $\mathrm{PD}$. The authors of this review concluded that there was a significant association of the PON1-55 MM + LM genotype with the risk of PD than the LL genotype and there was only a study for association between the polymorphism of PON1-192 and PD. However, some studies suggested that the M54L and Q192R polymorphisms were not major risk factors for PD. Also, we found that factors which increase paraoxonase activity; such as aspirin and oleic acid may reduce risk of PD. The roles of PON1 in PD is controversial, there is an essential need of future studies which provide a better understanding of roles of the PON1 in PD and pathogenic mechanisms of this disease.

\section{References}

1. Tyler KL, Tyler HR (1986) The secret life of James Parkinson (1755-1824) The writings of Old Hubert. Neurology 36: 222-224.

2. Duvoisin RC (1992) A brief history of parkinsonism. Neurol Clin 10: 301-316 [Crossref]

3. Gourie-Devi M., Ramu M., Venkataram B. (1991) Treatment of Parkinson's disease in'Ayurveda'(ancient Indian system of medicine): discussion paper. J R Soc Med 84 : 491-492. [Crossref]

4. Eriksen JL, Przedborski S, Petrucelli L (2005) Gene dosage and pathogenesis of Parkinson's disease. Trends Mol Med 11: 91-96. [Crossref]

5. Clarimon J, Eerola J, Hellstrom O, Tienari PJ, Singleton A (2004) Paraoxonase 1 (PON1) gene polymorphisms and Parkinson's disease in a Finnish population. Neurosci Lett 367: 168-170. [Crossref]

6. Fearnley JM, Lees AJ (1991) Ageing and Parkinson's disease: substantia nigra regional selectivity. Brain 114: 2283-2301. [Crossref]

7. Benmoyal-Segal L, Vander T, Shifman S, Bryk B, Ebstein RP, et al. (2005) Acetylcholinesterase/paraoxonase interactions increase the risk of insecticide-induced Parkinson's disease. FASEB J 19: 452-454. [Crossref]

8. Lang AE, Lozano AM (1998) Parkinson's disease. Second of two parts. N Engl J Med 339: 1130-1143. [Crossref]

9. Baba M, Nakajo S, Tu PH, Tomita T, Nakaya K, et al. (1998) Aggregation of alphasynuclein in Lewy bodies of sporadic Parkinson's disease and dementia with Lewy bodies. Am J Pathol 152: 879-884. [Crossref]

10. Ibanez P, Bonnet AM, Debarges B, Lohmann E, Tison F, et al,. (2004). Causal relation between a-synuclein locus duplication as a cause of familial Parkinson's disease. Lancet 364: 1169-1171. [Crossref]

11. Dorsey ER, Constantinescu R, Thompson JP, Biglan KM, Holloway RG, et al. (2007) Projected number of people with Parkinson disease in the most populous nations, 2005 through 2030. Neurology 68: 384-386. [Crossref]

12. Le Couteur DG, McLean AJ, Taylor MC, Woodham BL, Board PG (1999) Pesticides and Parkinson's disease. Biomed Pharmacother 53: 122-130. [Crossref]

13. Priyadarshi A, Khuder SA, Schaub EA, Priyadarshi SS (2001) Environmental risk factors and Parkinson's disease: a metaanalysis. Environ Res 86: 122-127. [Crossref]

14. Semchuk KM, Love EJ, Lee RG (1992) Parkinson's disease and exposure to agricultural work and pesticide chemicals. Neurology 42: 1328-1335. [Crossref]

15. Kondo I, Yamamoto M (1998) Genetic polymorphism of paraoxonase 1 (PON1) and susceptibility to Parkinson's disease. Brain Res 806: 271-273. [Crossref]

16. Marder K, Levy G, Louis ED, Mejia-Santana H, Cote L, et al. (2003) Accuracy of family history data on Parkinson's disease. Neurology 61: 18-23. [Crossref]

17. Barbeau A, Cloutier T, Roy M, Plasse L, Paris S, et al. (1985) Ecogenetics of Parkinson's disease: 4-hydroxylation of debrisoquine. Lancet 2: 1213-1216. [Crossref]

18. Franco R, Li S, Rodriguez-Rocha H, Burns M, Panayiotidis MI (2010) Molecular mechanisms of pesticide-induced neurotoxicity: Relevance to Parkinson's disease. Chem Biol Interact 188: 289-300. [Crossref]

19. Lopez O, Fernandez-Bolanos JG, Gil MV (2005) New trends in pest control: the search for greener insecticides. Green Chemistry 7: 431-442.

20. Manthripragada AD, Costello S, Cockburn MG, Bronstein JM, Ritz B (2010) Paraoxonase 1 (PON1), agricultural organophosphate exposure, and Parkinson disease. Epidemiology 21: 87-94. [Crossref] 
21. Ascherio A, Chen H, Weisskopf MG, O'Reilly E, McCullough ML, et al. (2006) Pesticide exposure and risk for Parkinson's disease. Ann Neurol 60: 197-203. [Crossref]

22. Frigerio R, Sanft KR, Grossardt BR, Peterson BJ, Elbaz A, et al,. (2006). Chemical exposures and Parkinson's disease: A population-based case-control study. Mov Disord 21: 1688-1692. [Crossref]

23. Behari M, Srivastava AK, Das RR, Pandey RM (2001) Risk factors of Parkinson's disease in Indian patients. J Neurol Sci 190: 49-55. [Crossref]

24. Nuti A, Ceravolo R, Dell'Agnello G, Gambaccini G, Bellini G, et al. (2004) Environmental factors and Parkinson's disease: a case-control study in the Tuscany region of Italy. Parkinsonism Relat Disord 10: 481-5. [Crossref]

25. Sarandol E, Tas S, Dirican M, Serdar Z (2005) Oxidative stress and serum paraoxonase activity in experimental hypothyroidism: effect of vitamin $\mathrm{E}$ supplementation. Cell Biochem Funct 23: 1-8. [Crossref]

26. Précourt LP, Amre D, Denis MC, Lavoie JC, Delvin E, et al. (2011) The three-gene paraoxonase family: physiologic roles, actions and regulation. Atherosclerosis 214: 2036. [Crossref]

27. Draganov DI, Stetson PL, Watson CE, Billecke SS, La Du BN (2000) Rabbit serum paraoxonase 3 (PON3) is a high density lipoprotein-associated lactonase and protects low density lipoprotein against oxidation. J Biol Chem 275: 33435-33442. [Crossref]

28. Teiber JF, Draganov DI, La Du BN (2003) Lactonase and lactonizing activities of human serum paraoxonase (PON1) and rabbit serum PON3. Biochem Pharmacol 66: 887-896. [Crossref]

29. Aldridge W (1953) Serum esterases. 2. An enzyme hydrolysing diethyl p-nitrophenyl phosphate (E 600) and its identity with the A-esterase of mammalian sera. Biochem $J$ 53: 117. [Crossref]

30. Primo-Parmo SL, Sorenson RC, Teiber J, La Du BN (1996) The human serum paraoxonase/arylesterase gene (PON1) is one member of a multigene family. Genomics 33: 498-507. [Crossref]

31. Mackness MI, Mackness B, Durrington PN, Connelly PW, Hegele RA (1996) Paraoxonase: biochemistry, genetics and relationship to plasma lipoproteins. Curr Opin Lipidol 7: 69-76. [Crossref]

32. Dahabreh IJ, Kitsios GD, Kent DM, Trikalinos TA (2010) Paraoxonase 1 polymorphisms and ischemic stroke risk: A systematic review and meta-analysis. Genet Med 12: 606-615. [Crossref]

33. Sogorb M, Pla A, Vilanova E (1996) Las esterasas que hidrolizan compuestos organofosforados: un mecanismo eficaz de destoxificación. Rev Toxicol 13: 43-48.

34. Mackness MI, Mackness B, Durrington PN (2002) Paraoxonase and coronary heart disease. Atheroscler Suppl 3: 49-55. [Crossref]

35. Vilanova E, Sogorb MA (1999) The role of phosphotriesterases in the detoxication of organophosphorus compounds. Crit Rev Toxicol 29: 21-57. [Crossref]

36. Hegele RA (1999) Paraoxonase genes and disease. Ann Med 31: 217-224. [Crossref]

37. Clendenning JB1, Humbert R, Green ED, Wood C, Traver D, et al. (1996) Structural organization of the human PON1 gene. Genomics 35: 586-589. [Crossref]

38. Durrington P, Mackness B, Mackness M (2001) Paraoxonase and atherosclerosis. Arterioscler Thromb Vasc Biol 21: 473-480. [Crossref]

39. Geldmacher-von Mallinckrodt M, Diepgen TL (1988) The human serum paraoxonasepolymorphism and specificity. Toxicol Environ Chem 18: 79-196.

40. Costa LG, Richter RJ, Li WF, Cole T, Guizzetti M, et al. (2003) Paraoxonase (PON 1) as a biomarker of susceptibility for organophosphate toxicity. Biomarkers 8: 1-12. [Crossref]

41. Billecke S, Draganov D, Counsell R, Stetson P, Watson C, et al. (2000) Human serum paraoxonase (PON1) isozymes Q and R hydrolyze lactones and cyclic carbonate esters. Drug Metab Dispos 28: 1335-1342. [Crossref]

42. Josse D, Masson P, Bartels C, Lockridge O (2002) PON1 structure. Paraoxonase (PON1) in Health and Disease: Springer PP. 27-52. [Crossref]

43. Dardiotis E, Xiromerisiou G, Hadjichristodoulou C, Tsatsakis AM, Wilks MF, et al (2013) The interplay between environmental and genetic factors in Parkinson's disease susceptibility: the evidence for pesticides. Toxicology 307: 17-23. [Crossref]

44. Adkins S, Gan KN, Mody M, La Du BN (1993) Molecular basis for the polymorphic forms of human serum paraoxonase/arylesterase: glutamine or arginine at position 191, for the respective A or B allozymes. Am J Hum Genet 52: 598-608. [Crossref]
45. Humbert R, Adler DA, Disteche CM, Hassett C, Omiecinski CJ, et al. (1993) The molecular basis of the human serum paraoxonase activity polymorphism. Nature 3 . 73-76. [Crossref]

46. Mackness B, Mackness MI, Arrol S, Turkie W, Julier K, et al. (1998) Serum paraoxonase (PON1) 55 and 192 polymorphism and paraoxonase activity and concentration in noninsulin dependent diabetes mellitus. Atherosclerosis 139: 341-349. [Crossref]

47. Brophy VH, Jampsa RL, Clendenning JB, McKinstry LA, Jarvik GP, et al. (2001) Effects of 5' regulatory-region polymorphisms on paraoxonase-gene (PON1) expression. Am J Hum Genet 68: 1428-1436. [Crossref]

48. Garin MC, James RW, Dussoix P, Blanché H, Passa P, et al. (1997) Paraoxonase polymorphism Met-Leu54 is associated with modified serum concentrations of the enzyme. A possible link between the paraoxonase gene and increased risk of cardiovascular disease in diabetes. J Clin Invest 99: 62. [Crossref]

49. Li WF, Costa LG, Richter RJ, Hagen T, Shih DM, et al. (2000) Catalytic efficiency determines the in-vivo efficacy of PON1 for detoxifying organophosphorus compounds. Pharmacogenetics 10: 767-779. [Crossref]

50. Davies HG, Richter RJ, Keifer M, Broomfield CA, Sowalla J, et al. (1996). The effect of the human serum paraoxonase polymorphism is reversed with diazoxon, soman and sarin. Nat Genet 14: 334-336. [Crossref]

51. Belin AC, Ran C, Anvret A, Paddock S, Westerlund M, et al. (2012) Association of a protective paraoxonase 1 (PON1) polymorphism in Parkinson's disease. Neurosci Let 522: 30-35. [Crossref]

52. Hadjigeorgiou GM, Malizos K, Dardiotis E, Aggelakis K, Dardioti M, et al. (2007) Paraoxonase 1 gene polymorphisms in patients with osteonecrosis of the femoral head with and without cerebral white matter lesions. J Ortho Res 25: 1087-1093. [Crossref]

53. Kokouva M, Koureas M, Dardiotis E, Almpanidou P, Kalogeraki A, et al. (2013) Relationship between the paraoxonase 1 (PON1) M55L and Q192R polymorphisms and lymphohaematopoietic cancers in a Greek agricultural population. Toxicology 307 12-16. [Crossref]

54. Haley RW, Billecke S, La Du BN (1999) Association of low PON1 type Q (type A) arylesterase activity with neurologic symptom complexes in Gulf War veterans. Toxicol Appl Pharmacol 157: 227-233. [Crossref]

55. Leviev I, Negro F, James RW (1997) Two Alleles of the Human Paraoxonase Gen Produce Different Amounts of mRNA An Explanation for Differences in Serum Concentrations of Paraoxonase Associated With the (Leu-Met54) Polymorphism. Arterioscler Thromb Vasc Biol 17: 2935-2939. [Crossref]

56. Akhmedova SN, Yakimovsky AK, Schwartz EI (2001) Paraoxonase 1 Met--Leu 54 polymorphism is associated with Parkinson's disease. J Neurol Sci 184: 179-182. [Crossref]

57. Fong CS, Cheng CW, Wu RM (2005) Pesticides exposure and genetic polymorphism of paraoxonase in the susceptibility of Parkinson's disease. Acta Neurol Taiwan 14: 55-60. [Crossref]

58. Leviev I, James RW (2000) Promoter polymorphisms of human paraoxonase PON1 gene and serum paraoxonase activities and concentrations. Arterioscler Thromb Vasc Biol 20: 516-521. [Crossref]

59. Nishio E, Watanabe Y (1997) Cigarette smoke extract inhibits plasma paraoxonase activity by modification of the enzyme's free thiols. Biochem Biophys Res Commun 236: 289-293. [Crossref]

60. Hedrick CC, Hassan K, Hough GP, Yoo JH, Simzar S, et al. (2000) Short-term feeding of atherogenic diet to mice results in reduction of HDL and paraoxonase that may be mediated by an immune mechanism. Arterioscler Thromb Vasc Biol 20: 1946-1952. [Crossref]

61. Karanth S, Pope C (2000) Carboxylesterase and A-esterase activities during maturation and aging: relationship to the toxicity of chlorpyrifos and parathion in rats. Toxicol $\mathrm{Sci}$ 58: 282-289. [Crossref]

62. Kim DS, Burt AA, Ranchalis JE, Richter RJ, Marshall JK, et al. (2012) Dietary cholesterol increases paraoxonase 1 enzyme activity. J Lipid Res 53: 2450-2458 [Crossref]

63. Kudchodkar BJ, Lacko AG, Dory L, Fungwe TV (2000) Dietary fat modulates serum paraoxonase 1 activity in rats. $J$ Nutr 130: 2427-2433. [Crossref]

64. Tavori H1, Aviram M, Khatib S, Musa R, Mannheim D, et al. (2011) Human carotid lesion linoleic acid hydroperoxide inhibits paraoxonase 1 (PON1) activity via reaction with PON1 free sulfhydryl cysteine 284. Free Radic Biol Med 50: 148-156. [Crossref] 
65. Fuhrman B, Volkova N, Aviram M (2006) Postprandial serum triacylglycerols and oxidative stress in mice after consumption of fish oil, soy oil or olive oil: possible role for paraoxonase-1 triacylglycerol lipase-like activity. Nutrition 22: 922-930. [Crossref]

66. Blatter-Garin MC, Kalix B, De Pree S, James RW (2003) Aspirin use is associated with higher serum concentrations of the anti-oxidant enzyme, paraoxonase-1. Diabetologia 46: 594-595. [Crossref]

67. Mackness B, Mackness MI, Arrol S, Turkie W, Durrington PN (1997) Effect of the molecular polymorphisms of human paraoxonase (PON1) on the rate of hydrolysis of paraoxon. Br J Pharmacol 122: 265-268. [Crossref]

68. Aviram M, Rosenblat M, Bisgaier CL, Newton RS, Primo-Parmo SL, et al. (1998) Paraoxonase inhibits high-density lipoprotein oxidation and preserves its functions. A possible peroxidative role for paraoxonase. J Clin Invest 101: 1581-1590. [Crossref]

69. Watson AD, Berliner JA, Hama SY, La Du BN, Faull KF, et al. (1995) Protective effect of high density lipoprotein associated paraoxonase. Inhibition of the biological activity of minimally oxidized low density lipoprotein. J Clin Invest 96: 2882-2891. [Crossref]

70. Cabana VG, Reardon CA, Feng N, Neath S, Lukens J, et al. (2003) Serum paraoxonase effect of the apolipoprotein composition of HDL and the acute phase response. $J$ Lipid Res 44: 780-7892. [Crossref]

71. Kumon Y, Suehiro T, Ikeda Y, Hashimoto K (2003). Human paraoxonase-1 gene expression by HepG2 cells is downregulated by interleukin-1 beta and tumor necrosis factor-a, but is upregulated by interleukin-6. Life Sci 73: 2807-2815. [Crossref]

72. Akcay MN, Polat MF, Yilmaz I, Akcay G (2003) Serum paraoxonase levels in pancreatic cancer. Hepatogastroenterology 50: Suppl 2:ccxxv-ccxxvii. [Crossref]

73. Kilic SS, Aydin S, Kilic N, Erman F, Aydin S, et al. (2005) Serum arylesterase and paraoxonase activity in patients with chronic hepatitis. World J Gastroenterol 11: 7351. [Crossref]

74. Tanimoto N, Kumon Y, Suehiro T, Ohkubo S, Ikeda Y, et al. (2003) Serum paraoxonase activity decreases in rheumatoid arthritis. Life sci 72: 2877-2885. [Crossref]

75. Ferretti G, Bacchetti T, Moroni C, Savino S, Liuzzi A, et al. (2005) Paraoxonase activity in high-density lipoproteins: a comparison between healthy and obese females. J Clin Endocrinol Metab 90: 1728-1733. [Crossref]

76. Chen Q, Reis SE, Kammerer CM, McNamara DM, Holubkov R, et al,. (2003) Association between the Severity of Angiographic Coronary Artery Disease and Paraoxonase Gene Polymorphisms in the National Heart, Lung, and Blood InstituteSponsored Women's Ischemia Syndrome Evaluation (WISE) Study. Am J Hum Genet 72: 13-22. [Crossref]

77. Mackness B, Durrington PN, Abuashia B, Boulton AJ, Mackness MI (2000) Low paraoxonase activity in type II diabetes mellitus complicated by retinopathy. Clin Sci 98: 355-363.

78. Janka Z., Juhasz A., Rimanoczy A., Boda K., Marki-Zay J., Kalman J. (2002). Codon 311 (Cys? Ser) polymorphism of paraoxonase-2 gene is associated with apolipoprotein E4 allele in both Alzheimer's and vascular dementias. Mol Psychiatry 7: 110-112 [Crossref]

79. Fortunato G, Rubba P, Panico S, Trono D, Tinto N, et al. (2003) A paraoxonase gene polymorphism, PON 1 (55), as an independent risk factor for increased carotid intimamedia thickness in middle-aged women. Atherosclerosis 167: 141-148. [Crossref]

80. Serhatlioglu S, Gursu MF, Gulcu F, Canatan H, Godekmerdan A (2003) Levels of paraoxonase and arylesterase activities and malondialdehyde in workers exposed to ionizing radiation. Cell Biochem Funct 21: 371-375. [Crossref]

81. Antognelli C, Mearini L, Talesa VN, Giannantoni A, Mearini E (2005) Association of CYP17, GSTP1, and PON1 polymorphisms with the risk of prostate cancer. Prostate 63: 240-251. [Crossref]

82. Marchesani M1, Hakkarainen A, Tuomainen TP, Kaikkonen J, Pukkala E, et al. (2003) New paraoxonase 1 polymorphism I102V and the risk of prostate cancer in Finnish men. J Natl Cancer Inst 95: 812-818. [Crossref]

83. Lurie G, Wilkens LR, Thompson PJ, McDuffie KE, Carney ME, et al. (2008) Genetic polymorphisms in the Paraoxonase 1 gene and risk of ovarian epithelial carcinoma. Cancer Epidemiol Biomarkers Prev 17: 2070-2077. [Crossref]

84. Camuzcuoglu H, Arioz DT, Toy H, Kurt S, Celik H, et al. (2009). Serum paraoxonase and arylesterase activities in patients with epithelial ovarian cancer. Gynecol Oncol 112: 481-485. [Crossref]

85. McElveen J, Mackness MI, Colley CM, Peard T, Warner S, et al. (1986) Distribution of paraoxon hydrolytic activity in the serum of patients after myocardial infarction. Clin Chem 32: 671-673. [Crossref]

86. Simon T, Steg PG, Becquemont L, Verstuyft C, Kotti S, et al. (2011) Effect of paraoxonase-1 polymorphism on clinical outcomes in patients treated with clopidogrel after an acute myocardial infarction. Clin Pharmacol Ther 90: 561-567. [Crossref]
87. Li J, Wang X, Huo Y, Niu T, Chen C, et al. (2005) PON1 polymorphism, diabetes mellitus, obesity, and risk of myocardial infarction: Modifying effect of diabetes mellitus and obesity on the association between PON1 polymorphism and myocardial infarction. Genet Med 7: 58-63. [Crossref]

88. Rosenblat M, Sapir O, Aviram M (2008) Glucose inactivates paraoxonase 1 (PON1) and displaces it from high density lipoprotein (HDL) to a free PON1 form. The paraoxonases: their role in disease development and xenobiotic metabolism. Springer 10: 35-49.

89. Elkiran ET, Mar N, Aygen B, Gursu F, Karaoglu A, et al. (2007) Serum paraoxonase and arylesterase activities in patients with lung cancer in a Turkish population. $B M C$ Cancer 7: 48. [Crossref]

90. Stevens VL, Rodriguez C, Pavluck AL, Thun MJ, Calle EE (2006). Association of polymorphisms in the paraoxonase 1 gene with breast cancer incidence in the CPS-Il Nutrition Cohort. Cancer Epidemiol Biomarkers Prev 15: 1226-1228. [Crossref]

91. Baskol G, Demir H, Baskol M, Kilic E, Ates F, et al. (2005) Assessment of paraoxonase 1 activity and malondialdehyde levels in patients with rheumatoid arthritis. Clin Biochem 38: 951-955. [Crossref]

92. Ferre N, Camps J, Prats E, Vilella E, Paul A, et al,. (2002). Serum paraoxonase activity: a new additional test for the improved evaluation of chronic liver damage. Clin Chem 48: 261-268. [Crossref]

93. Sabesin SM, Hawkins HL, Kuiken L, Ragland JB (1977) Abnormal plasma lipoproteins and lecithin-cholesterol acyltransferase deficiency in alcoholic liver disease. Gastroenterology 72: 510-518. [Crossref]

94. Tward A, Xia YR, Wang XP, Shi YS, Park C, et al. (2002) Decreased atherosclerotic lesion formation in human serum paraoxonase transgenic mice. Circulation 106: 484490. [Crossref]

95. Rozenberg O, Shih DM, Aviram M (2003) Human Serum Paraoxonase 1 Decreases Macrophage Cholesterol Biosynthesis Possible Role for Its Phospholipase-A2-Like Activity and Lysophosphatidylcholine Formation. Arterioscler Thromb Vasc Biol 23: 461-467. [Crossref]

96. Ayub A, Mackness MI, Arrol S, Mackness B, Patel J, et al. (1999) Serum paraoxonase after myocardial infarction. Arterioscler Thromb Vasc Biol 19: 330-335. [Crossref]

97. Mackness MI, Harty D, Bhatnagar D, Winocour PH, Arrol S, et al. (1991) Serum paraoxonase activity in familial hypercholesterolaemia and insulin-dependent diabetes mellitus. Atherosclerosis 86: 193-199. [Crossref]

98. Lawlor DA, Day IN, Gaunt TR, Hinks LJ, Timpson N, et al. (2007) The association of the paraoxonase (PON1) Q192R polymorphism with depression in older women: findings from the British Women's Heart and Health Study. J Epidemiol Community Health 61: 85-87. [Crossref]

99. Bhattacharyya T, Nicholls SJ, Topol EJ, Zhang R, Yang X, et al. (2008) Relationship of paraoxonase 1 (PON1) gene polymorphisms and functional activity with systemic oxidative stress and cardiovascular risk. JAMA 299 11: 1265-1276. [Crossref]

100. Saeed M, Siddique N, Hung WY, Usacheva E, Liu E, et al. (2006) Paraoxonase cluste polymorphisms are associated with sporadic ALS. Neurology 67: 771-776. [Crossref]

101. Perez-Herrera N, Polanco-Minaya H, Salazar-Arredondo E, Solis-Heredia M Hernandez-Ochoa I, et al. (2008) PON1Q192R genetic polymorphism modifies organophosphorous pesticide effects on semen quality and DNA integrity in agricultural workers from southern Mexico. Toxicol Appl Pharmacol 230: 261-268. [Crossref]

102. Carmine A, Buervenich S, Sydow O, Anvret M, Olson L (2002) Further evidence for an association of the paraoxonase 1 (PON1) Met-54 allele with Parkinson's disease. Mov Disord 17: 764-766. [Crossref]

103. Duric G, Svetel M, Nikolaevic SI, Dragadevic N, Gavrilovic J, et al. (2007) Polimorfizmi gena citohrom oksidaze P450 2D6 (CYP2D6), paraoksonaze 1 (PON1) i apolipoproteina (APOE) kao faktori rizika od razvoja Parkinsonove bolesti. Vojnosanitetski Pregled: Military Medical \& Pharmaceutical Journal of Serbia \& Montenegro 64: 25-30.

104. Dick FD, De Palma G, Ahmadi A, Osborne A, Scott NW, et al. (2007). Geneenvironment interactions in parkinsonism and Parkinson's disease: the Geoparkinson study. Occup Environ Med 64: 673-680. [Crossref]

105. Wingo TS, Rosen A, Cutler DJ, Lah JJ, Levey AI (2012) Paraoxonasepolymorphisms in Alzheimer's disease, Parkinson's disease, and AD-PD spectrum diseases. Neurobiol Aging 33: 204.e13-204.e15. [Crossref]

Copyright: (C2019 Mota A. This is an open-access article distributed under the terms of the Creative Commons Attribution License, which permits unrestricted use, distribution, and reproduction in any medium, provided the original author and source are credited. 